\title{
NUCLEOPROTEIN-LATEX AGGLUTINATION TEST IN CONNECTIVE TISSUE DISEASES ${ }^{*}$
}

\author{
BY \\ W. J. FESSEL + \\ From the Rheumatic Disease Group of the Department of Medicine, University of California \\ School of Medicine, San Francisco, California
}

Research into the aetiology of the collagen diseases has been guided recently by the speculation that they may be manifestations of hypersensitivity. Rheumatoid arthritis and disseminated lupus erythamatosus especially, it has been suggested, could be the results of "auto-immune" processes. The work of Klemperer, Gueft, Lee, Leuchtenberger, and Pollister (1950) focused attention on the role of deoxyribosenucleic acid in disseminated lupus erythematosus. Subsequently, Miescher and Strässle (1957) described deoxyribosenucleic acid antibodies in the disease. These investigators used haemagglutination of sensitized sheep red cells to estimate antibody titres, but suggested that latex particles might also be used. Christian, Mendez-Bryan, and Larson (1958) recently described the use of latex particles sensitized with nucleoprotein as a test for disseminated lupus erythematosus. This report describes our results with a nucleoprotein-latex agglutination test on the sera of patients with lupus, rheumatoid arthritis, and certain other diseases. We also performed F II haemagglutination tests (method of Jacobson, Kammerer, Wolf, Epstein, and Heller, 1956) on most of these sera.

\section{Materials and Methods}

(1) Deoxyribosenucleoprotein was obtained by the standard method (Zamenhof, 1957) of washing a homogenate of calf thymus in 0.1 molar sodium citrate and subsequently extracting the nucleoprotein with 1 molar sodium chloride. The nucleoprotein was precipitated twice by making the solution 70 per cent. with respect to ethyl alcohol, and the nucleoprotein fibres finally

* This study was supported in part by a grant (A-1229) from the National Institutes of Health, Arthritis and Metabolic Diseases, and by a grant from Geigy Pharmaceuticals, Yonkers, New York.

+ Read in part at the meeting of the Western Society for Clinical

Research, Carmel, California, January, 1959.

$\ddagger$ Trainee of the National Institutes of Health, United States Public Health Service. dissolved in 1 molar saline. The nucleoprotein from $50 \mathrm{~g}$. calf thymus was dissolved in $100 \mathrm{ml}$. molar saline, and had a nitrogen/phosphorus ratio of $331 / 96$. The nucleoprotein was stored frozen, and retained its activity for at least 5 months.

(2) The nucleoprotein-latex agglutination test was performed as follows: Polystyrene latex of particle size 0.81 micra was diluted with distilled water so that the final light transmission of a 1 per cent. solution was 5 per cent. in a spectrophotometer at 650 millimicra with a red filter. The final test solution contained 1 per cent. of this latex suspension, 1 per cent. of the nucleoprotein solution, and 98 per cent. of glycine-saline buffer $\mathrm{pH} 8 \cdot 2$.

Serial doubling dilutions of the test sera were made in the range of $1: 2$ to $1: 4096$, using the $\mathrm{pH} 8 \cdot 2$ buffer as diluent. To each dilution was added an equal volume $(0.25 \mathrm{ml}$.) of nucleoprotein-latex suspension. The tubes were incubated at $37^{\circ} \mathrm{C}$. for $2 \mathrm{hrs}$, then centrifuged for 3 mins. at 1,750 r.p.m. The resulting agglutination was read and graded 1 plus $(+)$ to 4 plus $(++++)$. Agglutination in any dilution greater than 1 plus was regarded as positive.

We did not centrifuge and wash the sensitized latex particles as did Christian and others (1958); we found this arduous manœuvre unnecessary. Any nucleoprotein fibres which form may be lifted out before the sensitized latex suspension is added to the serum dilutions. Our titres are comparable to those reported by Christian and others (1958), who washed the sensitized latex several times.

(3) Any serum causing agglutination was tested against unsensitized latex particles. For a positive test at least a twofold dilution difference was required between the agglutination in the sensitized and unsensitized latex particle system.

(4) L.E. cell preparations were made by mixing four drops of the buffy layer of heparinized blood with six drops of the serum under test. The temperature of all reagents and glassware was kept at $37^{\circ} \mathrm{C}$. The mixture was incubated for $2 \mathrm{hrs}$ at this temperature, then gently centrifuged. A smear was made of the sediment. Each 
slide was examined for at least $15 \mathrm{~min}$. before being pronounced negative.

(5) Sera for testing were obtained as follows:

(a) Rheumatoid sera were derived from specimens sent to this laboratory for routine F II haemagglutination tests.

(b) Sera were obtained from patients with disseminated lupus seen at this hospital over the past 2 years. Sera from similar patients were also donated by colleagues in private practice.

(c) Sera of patients with discoid lupus were obtained from the Dermatology Clinic.

(d) "Normal" sera consisted of those received by the blood bank for typing. They were, therefore, both from normal persons and from patients with miscellaneous diseases.

(6) F II haemagglutination tests were performed by the standard technique (Jacobson and others, 1956).

\section{Results}

The results of tests with latex sensitized with nucleoprotein are shown in the Table. Titres ranging from $1: 2$ to $1: 4096$ were obtained using latex particles sensitized with nucleoprotein.

(1) Of 159 "normal" sera, three (1.9 per cent.) were positive. One (from a patient with spinal cord meningioma) had a titre of only $1: 2$, the other two had titres of $1: 16$ (a case of infectious hepatitis) and $1: 256$ (a case of Ehlers-Danlos syndrome). None of these three sera produced L.E. cells.

(2) Of sera from ten patients who had chronic discoid lupus, none caused latex agglutination or produced L.E. cells.

(3) Of 37 sera from patients with disseminated lupus erythematosus, 25 (68 per cent.) had positive latex tests in a titre ranging from $1: 2$ to $1: 1024$;
26 (70 per cent.) of the 37 sera produced L.E. cells, and 22 ( 88 per cent.) of the 25 with positive latex tests gave a positive L.E. cell reaction. Of the twelve disseminated lupus erythematosus sera which did not agglutinate latex, four produced L.E. cells. Of the 25 disseminated lupus erythematosus sera which agglutinated latex, thirteen ( 52 per cent.) had positive F II haemagglutination tests. The percentage of the total group of disseminated lupus erythematosus sera which gave positive F II haemagglutination tests cannot be given since sufficient serum was not available in every case for testing. $\overrightarrow{0}$ There was no correlation between the level of the $\overrightarrow{\vec{J}}$ nucleoprotein latex titre and the level of the F II $\tilde{o}^{\omega}$ titre.

(4) In rheumatoid arthritis, 33 (22 per cent.) of a total of 150 sera were positive. Among the $150 \stackrel{\infty}{\omega}$ sera were ten from patients considered to be in the is phase of rheumatoid arthritis which is accompanied of by widespread arteritis and is characterized especially by neurovascular lesions. Only two of these ten sera were positive (titres of $1: 4$ and $1: 16$ ); $\mathscr{D}$ neither produced L.E. cells. Only one of these ten $\frac{\mathbb{O}}{\mathbb{P}}$ sera produced L.E. cells, and this one gave a $\frac{\mathbb{D}}{3}$ negative nucleoprotein-latex test. Two of the remaining 31 positive rheumatoid sera produced L.E. cells. The nucleoprotein-latex titre of these $\vec{c}$ two was $1: 16$ and $1: 1024$, and the correspondin F II haemagglutination titres were $>1: 56,000$ ard $1: 56,000$ respectively. There was no apparent relationship between the F II haemagglutination titre and nucleoprotein-latex titre in either the lupus or the rheumatoid sera.

(5) In a group of eighteen sera, all positive in $\overrightarrow{\overrightarrow{0}}$ either or both the Kolmer and Kahn tests, seven 3 were positive in the nucleoprotein-latex test in titres ranging from $1: 2$ to $1: 32$. Three of the seven had unquestionable syphilis, having either taboparesis or aortic aneurysms. Examination of the

TABLE

COMPARISON OF RESULTS OF NUCLEOPROTEIN-LATEX AND L.E. CELL TESTS

\begin{tabular}{|c|c|c|c|c|c|c|c|}
\hline \multirow{2}{*}{ Results of Tests } & \multirow{2}{*}{$\cdots$} & Latex & \multirow{2}{*}{$\begin{array}{l}\text { Positive } \\
\text { Positive }\end{array}$} & \multirow{2}{*}{$\begin{array}{c}\text { Positive } \\
\text { Negative }\end{array}$} & \multirow{2}{*}{$\frac{\text { Negative }}{\text { Positive }}$} & \multirow{2}{*}{$\begin{array}{l}\text { Negative } \\
\text { Negative }\end{array}$} & \multirow{2}{*}{$\begin{array}{c}\text { Total No. } \\
\text { of Tests }\end{array}$} \\
\hline & & L.E. Cell & & & & & \\
\hline \multirow{6}{*}{ Types of Sera } & "Normal" & & 0 & 3 & 0 & 156 & 159 \\
\hline & \multirow{2}{*}{ Lupus Erythematosus } & Chronic discoid & 0 & 0 & 0 & 10 & 10 \\
\hline & & Disseminated ... & 22 & 3 & 4 & 8 & 37 \\
\hline & \multirow{2}{*}{ Rheumatoid Arthritis } & Without arteritis & 2 & 31 & 0 & 107 & 140 \\
\hline & & With arteritis ... & 0 & 2 & 1 & 7 & 10 \\
\hline & \multicolumn{2}{|c|}{ Showing Positive Tests for Syphilis } & 1 & 6 & 0 & 11 & 18 \\
\hline
\end{tabular}


records of the other four leads one to suspect that they may have had biologic false positive tests for syphilis. Unfortunately, the results of Treponema pallidum immobilization tests are not available. One of these seven sera produced classical L.E. cells. The record revealed that this serum was from a 45-year-old coloured female who had had chronic uveitis for 6 months. We think it likely that this patient will eventually develop signs of disseminated lupus erythematosus.

\section{Discussion}

Our results confirm the usefulness of a nucleoprotein-latex test in disseminated lupus erythematosus, since the sera from 68 per cent. of such patients in our series gave a positive result. The test is much easier to perform than the classical L.E. cell test and, in addition, allows for some quantitation of the amount of "lupus factor" present. The occurrence of positive tests in diseases other than disseminated lupus erythematosus may mean that the test is sufficiently sensitive to detect small amounts of the "lupus factor", or a related substance, in those diseases.

The results of the test in rheumatoid arthritis confirm again the well-known fact that "lupus factor" is found in about 20 to 25 per cent. of patients with that disease (Friedman, Sickley, Poske, Black, Bronsky, Hartz, Feldhake, Reeder, and Katz, 1957). It has been known for some years that the sera of many patients with disseminated lupus erythematosus give a positive reaction in serological tests for syphilis. Miller, Slatkin, Brodey, Wechsler, and Hill (1957) reported that serological tests for syphilis were positive in eleven of fourteen cases of acute disseminated lupus erythematosus with L.E. cells. Moore and Mohr (1952) stated that there was a 20 per cent. incidence of biologic false positive tests for syphilis in lupus erythematosus. It is of interest that seven of the eighteen sera in our series which were positive for syphilis also were positive in the nucleoprotein-latex test. At least one of these seven patients has probable lupus, three have undoubted syphilis, and three are probably biologic false positives. It is, of course, not known exactly what is being titrated in the nucleoprotein-latex test; there is a strong suspicion that nucleoprotein antibodies are being measured, especially since preliminary studies in our laboratories show that rabbits immunized with nucleoprotein injections produce serum which strongly agglutinates the test system. However, the fact that undoubted syphilitic sera agglutinate the latex suggests that something other than nucleoprotein antibodies may be involved.
Dameshek (1958) recently postulated that disseminated lupus erythematosus may be a complex of auto-immune abnormalities involving various constituents of the blood and endothelial surfaces. Our results confirm that, whatever initiates the disturbance in disseminated lupus erythematosus, the resulting immunological abnormalities are multiple and include nucleoprotein antibodies as well as the antibodies found in syphilis. The important question of which factor or factors are primary remains unanswered. It would seem most unlikely that nucleoprotein antibodies alone are primary, since Bardawil, Toy, Galins, and Bayles (1958) have shown, and we have confirmed in our laboratory, that high circulating levels of nucleoprotein antibodies in animals do not lead to the production of the histological lesions of lupus in these animals.

\section{Summary}

The usefulness of a nucleoprotein-latex test in the diagnosis of lupus erythematosus has been confirmed. The test was positive in 68 per cent. of patients with disseminated lupus erythematosus, in 22 per cent. of patients with rheumatoid arthritis, and in only 1.9 per cent. of patients with other diseases excluding syphilis. In sera giving positive tests for syphilis, 39 per cent. were positive. In disseminated lupus erythematosus the test correlated well with the L.E. cell test.

\section{REFERENCES}

Bardawil, W. A., Toy, B. L., Galins, N., and Bayles, T. B. (1958) Amer. J. Path., 34, 607.

Christian, C. L., Mendez-Bryan, R., and Larson, D. L. (1958). Proc. Soc. exp. Biol. (N.Y.), 98, 820

Dameshek, W. (1958). Ann. intern. Med., 48, 707.

Friedman, I. A, Sickley, J. F., Poske, R. M., Black, A., Bronsky, D. Hartz, W. H., Feldhake, C., Reeder, P. S., and Katz, E. M. (1957). Ibid., 46, 1113.

Jacobson, A. S., Kammerer, W. H., Wolf, J., Epstein, W. V., and Heller, G. (1956). Amer. J. Med., 20, 490.

Klemperer, P., Gueft, B., Lee, S. L., Leuchtenberger, C., and Pollister, A. W. (1950). Arch. Path. (Chicago), 49, 503.

Miescher, P., and Strässle, R. (1957). Vox sang. (Basel), N.S. 2, 283 Miller, J. L., Slatkin, M. H., Brodey, M., Wechsler, H. L., and Hill, J. H.' (1957). J. Amer. med. Ass., 154, 1241 .

Moore, J. E. (1957). J. Amd Mohr, C. F. (1952). Ibid., 150, 467.

Moore, J. E., and Mohr, C. F. (1952). Ibid., 150, 467., ed. S. P. Colowick and N. O. Kaplan, vol. 3, p. 696. Academic Press, Inc., New York.

\section{Réaction d'agglutination nucléoprotéine-latex dans les maladies du tissu conjonctif}

\section{RÉSUMÉ}

On a confirmé l'importance de la réaction nucléoprotéine-latex dans le diagnostic du lupus érythémateux. Cette réaction était positive dans $68 \%$ des cas de lupus érythémateux disséminé, dans $22 \%$ des cas d'arthrite rhumatismale et seulement dans $1,9 \%$ des malades atteints d'autres maladies, sauf la syphilis. Parmi les sérums donnant une réaction syphilitique positive, notre réaction était positive dans $39 \%$ des cas. Dans le lupus érythémateux disséminé il y avait une bonne corrélation entre cette réaction et le phénomène L.E. 
Reacción de aglutinación de nucleoproteina-latex en las enfermedades del tejido conjuntivo

\section{SUMARIO}

Se confirmó la importancia de la reacción de nucleoproteina-latex para el diagnóstico del lupus eritematoso. Esta reacción fué positiva en el $68 \%$ de los casos de lupus eritematoso diseminado, en el $22 \%$ de los casos de artritis reumatoide y sólo en un $1,9 \%$ de casos con $\Xi$ otras enfermedades, excepto la sífilis. Para sueros con reacción sifilítica positiva, nuestra reacción dió una reacción positiva en un $39 \%$ de los casos. En el lupus eritematoso diseminado hubo una buena correlación $\overrightarrow{\bar{F}}$ entre esta reacción y el fenómeno L.E. 